\title{
Microstructure and mechanical properties of AA5086 aluminum alloy by friction stir welding
}

\author{
K. Amini*, F. Gharavi** \\ *Department of Mechanical Engineering, Tiran Branch, Islamic Azad University, Isfahan, Iran \\ **Materials Synthesis and Characterization Laboratory, Institute of Advanced Technology, Universiti Putra Malaysia, \\ 43400 UPM Serdang, Selangor, Malaysia
}

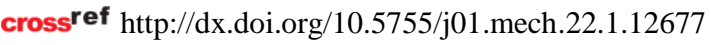

\section{Introduction}

Currently, aluminium alloys are used as alternative to steel in many applications because of their light weight, good weldability, and formability as well as good strength and corrosion resistance [1]. Among aluminium alloys, the $5 \times x x$ series are aluminium alloys with magnesium as a main element and its value is about $1 \%$ to $5 \%$ which is combined with a small amount of manganese or chromium [1-3]. AA5086 aluminium alloy is a non-age hardening and non-heat treatable alloy with high strength, good corrosion resistance, and desirable formability and weldability. It has become widely used in automotive, marine, transportation, and aerospace industries [1, 2]. The growing applications of the aluminium alloys, especially the AA5xxx alloys, have encountered many challenges in different industries to join them together by welding processes. In this regard, fusion welding process, as the most common welding method, is used to join aluminium alloys. Since fusion welding techniques have common defects such as inclusion, cracks in the weld, and tensile residual stress, using of these methods has become restricted to critical industry applications.

Friction stir welding (FSW) is a well-recognized method for joining aluminium alloys and other materials which was invented as a replacement method to fusion joining processes by the welding institute (TWI) in 1991. Since this process is a solid-state welding method and joining with this process takes place below the melting temperature of the material; therefore, by using this process, porosity and hot cracking defects, often generated with fusion welding, are largely eliminated with resulting improved mechanical and corrosion properties [4, 5]. As the heat generated may alter the alloy microstructure, the process has a great influence on microstructure; it substitutes the coarse grains of the post welded aluminium alloy with small equiaxed grains within the weld nugget zone (WNZ) and deformed elongated ones at the thermo-mechanical affected zone (TMAZ) edges due to the dynamic recrystallization process resulting from the frictional heat and severe mechanical deformation $[4,5]$. As a result of the severe mechanical deformation caused by the tool rotation effect, the majority of the coarse constituent particles that are present within the matrix alloy in random distribution are fragmented to finer and more uniformly intermetallics within the weld nugget. Such an effect was observed by Dilip et al [6] who recorded intermetallic particles of smaller size and higher density within the weld nugget of the friction stir welded AA2219-T87 and AA5083-H321 compared with the ones within the parent alloys. In the present investigation, the effect of welding speed on microstructure of the non-heat treatable AA5086 aluminium alloy is evaluated in terms of size and distribution of intermetallic particles and microstructure is correlated to mechanical properties of the weld regions and parent alloy. Mechanical properties are assessed by measuring the hardness profile along the weld regions and tensile properties of the weldments.

\section{Experimental procedure}

The investigated alloy was a 5086 aluminium alloy plate with the thickness of $8 \mathrm{~mm}$. The chemical composition and mechanical properties of the aluminum alloy are listed in Table 1. The plates were cut into rectangular welding samples to the required dimensions (300 mm $\times 100 \mathrm{~mm} \times 8 \mathrm{~mm}$ ) by wire cut electric discharge machine. The butt joint configuration was performed by mechanical clamping the plates in position to the backing plate. A vertical- spindle type milling machine was used as a friction stir welding machine to fabricate the weldments. The direction of welding was perpendicular to the rolling direction of the plates and single pass of the FSW process was performed to produce the joints. The welding tool size and welding parameters are shown in Table 2.

Chemical compositions and mechanical properties of 5086 aluminum alloy

Table 1

\begin{tabular}{|c|c|c|c|c|c|c|c|c|}
\hline \multicolumn{7}{|c|}{ Chemical Compositions, wt.\% } \\
\hline Al & $\mathrm{Mg}$ & $\mathrm{Mn}$ & $\mathrm{Cr}$ & $\mathrm{Cu}$ & $\mathrm{Fe}$ & $\mathrm{Si}$ & $\mathrm{Ti}$ & $\mathrm{Zn}$ \\
\hline Bal. & 4.1 & 0.5 & 0.2 & 0.15 & 0.45 & 0.35 & 0.1 & 0.1 \\
\hline
\end{tabular}

\begin{tabular}{|c|c|c|}
\hline \multicolumn{3}{|c|}{ Mechanical Properties } \\
\hline Tensile strength, MPa & Elongation, \% & Hardness, HV \\
\hline 345 & 12 & 88 \\
\hline
\end{tabular}

Table 2

Tool size and welding parameters used in the experiments

\begin{tabular}{|c|c|c|c|c|c|}
\hline \multicolumn{3}{|c|}{ Tool size, $\mathrm{mm}$} & \multicolumn{3}{|c|}{ Welding parameters } \\
\hline Shoulder diameter & Pin diameter & Pin length & Rotation speed, rpm & Welding speed, $\mathrm{mm} / \mathrm{min}$ & Tool tilt, $^{\circ}$ \\
\hline 20 & 8 & 7.5 & 1000 & $63-100$ & 3 \\
\hline
\end{tabular}


In order to identify the weld regions, macro etching was conducted. Before etching, weldment specimens with dimensions of $50 \times 8 \times 8 \mathrm{~mm}$ with the welding line at the center were mechanically ground at cross section surface with 400-1500 SiC grit papers, and were polished using $1 \mu \mathrm{m}$ diamond paste, washed with distilled water, cleaned with ethanol, and dried in cold stream of air. Finally, the specimens were etched in a solution of $10 \mathrm{wt} \%$ caustic soda $(\mathrm{NaOH})$ and $90 \mathrm{ml}$ of distilled water at $65^{\circ} \mathrm{C}$ for 30 seconds, washed immediately with distilled water, dried and rinsed in $70 \%$ concentrated nitric acid for 30 seconds before optical microscopy (OM) examination.

For revealing the effect of welding speeds on the size, shape, and distribution of intermetallic particles, a scanning electron microscopy (SEM) with x-ray energy dispersive spectroscopy (EDS) system was utilized to verify such effect. Furthermore, micro-hardness measurement was performed at the mid-thickness of cross section of the prepared specimens with $2 \mathrm{~mm}$ spacing between the adjacent indentations. The testing load was $0.1 \mathrm{~kg}$ for $10 \mathrm{sec}-$ onds. In addition, the transverse tensile specimens were prepared according to the ASTM B557-02 standard. Room temperature tensile test was carried out at a strain rate of
$2 \mathrm{~mm} / \mathrm{min}$ by using a $100 \mathrm{KN}$ Instron mechanical testing machine. To evaluate the tensile properties, three tensile specimens were examined to find the average weld strength for a process condition.

\section{Results and discussion}

\subsection{Macro-structures of the weldments}

Fig. 1 presents the macroscopic appearance of the weldments at various welding speeds. The weldments can be observed without any welding defects at the welding speeds of $63-100 \mathrm{~mm} / \mathrm{min}$. Due to the lowering of material flow level around the tool pin, the nugget size decreases with increasing the welding speed. In other words, the time required to create mechanical changes and to involve the grains and intermetallic particles around the tool pin decreases with increasing the welding speed. This lowering time is accompanied with higher cooling rate in the weld region which does not allow the formation of material flow with high level around the tool pin and therefore, the nugget size has become smaller at higher welding speeds $[4,7,8]$.

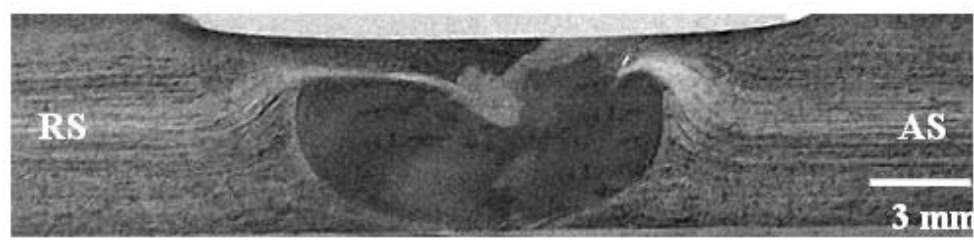

a

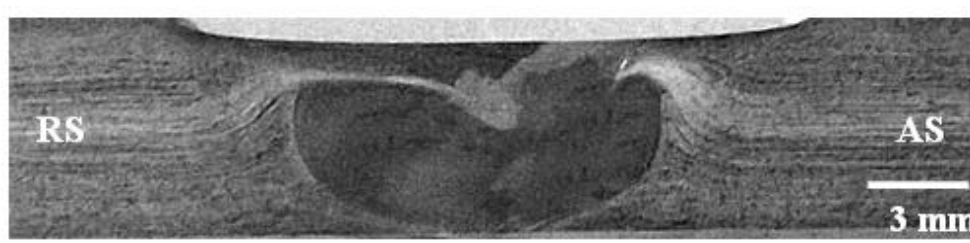

b

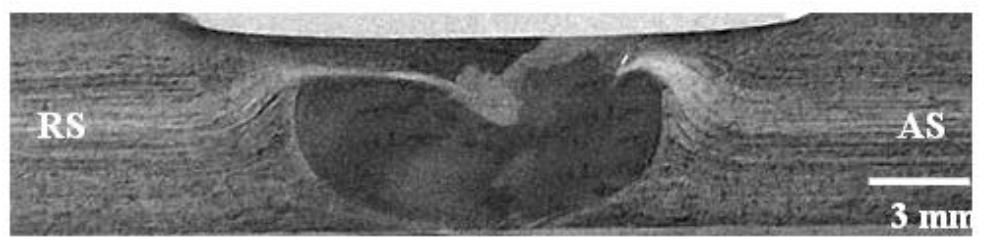

c

Fig. 1 Cross section of the joints welded at different welding speeds: a $-63 \mathrm{~mm} / \mathrm{min} ; \mathrm{b}-80 \mathrm{~mm} / \mathrm{min} ; \mathrm{c}-100 \mathrm{~mm} / \mathrm{min}$

\subsection{Micro-structures of the Parent Alloy}

The SEM examinations were conducted to identify the various intermetallic compounds present in the weld regions and parent alloy. As Also, their compositions were evaluated using EDS. Fig. 2 shows the size, shape, and distributions of the intermetallic precipitate phases in the parent alloy (PA). The EDS analysis is presented in Fig. 3.

It is clear that the compounds of precipitate that are pointed with 1 and 2 mostly consist of $\mathrm{Al}$ (Fe-Mn) and $\mathrm{Al}$ (Fe-Mn-Cr) which are distributed as a bright tone in the matrix; Those pointed by 3 basically contain $\mathrm{Al}(\mathrm{Mg}-\mathrm{Si})$ which are denoted as a gray tone, while those pointed by 4 mainly contain $\mathrm{Al}$ and $\mathrm{Mg}$ which are distributed as a graylight tone in the Al matrix. Significantly, the mentioned precipitates are different in terms of composition and size. Accordingly, the $\mathrm{Al}(\mathrm{Fe}-\mathrm{Mn})$ and $\mathrm{Al}(\mathrm{Fe}-\mathrm{Mn}-\mathrm{Cr})$ precipitates contain higher particle size, so that some of these particles were found with a mean size of about $75 \mu \mathrm{m}^{2}$ while the surface area of the others is approximately $4 \mu \mathrm{m}^{2}$. On the other hand, the $\mathrm{Al}(\mathrm{Mg}-\mathrm{Si})$ particles present an area of about $3 \mu \mathrm{m}^{2}$ and those of $\mathrm{Al}-\mathrm{Mg}$ approximately $7 \mu \mathrm{m}^{2}$. In addition, it was noted that the amount of distribution of these particles is also different, so that the particles of $\mathrm{Al}(\mathrm{Fe}-\mathrm{Mn})$ and $\mathrm{Al}-\mathrm{Mg}$ contain the most abundant and the least numerous, respectively. 


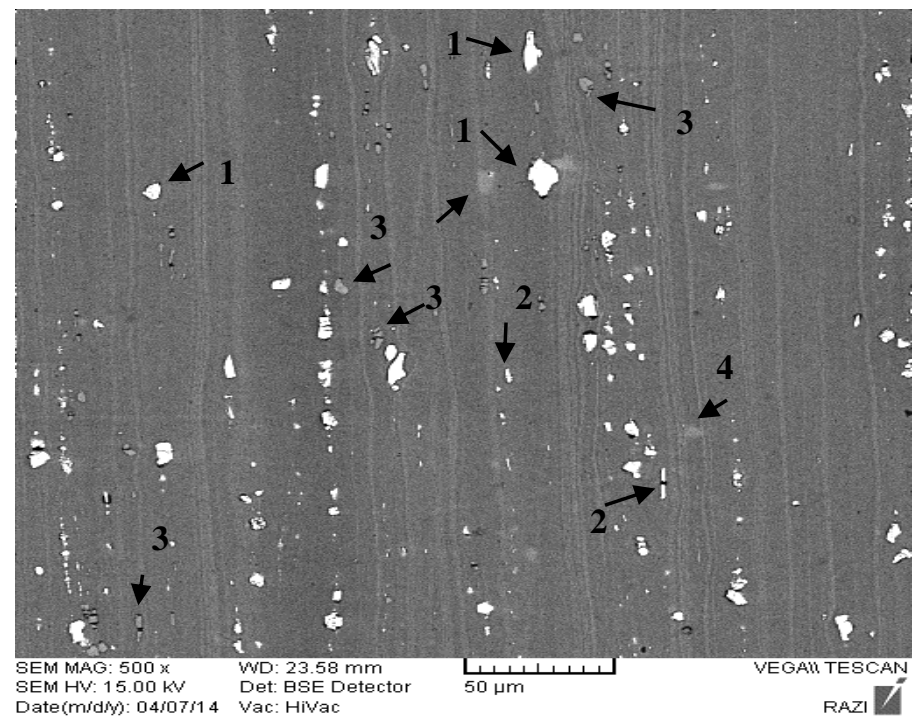

Fig. 2 SEM micrograph image of intermetallic identified in parent alloy (1) $\mathrm{Al}$ (Fe-Mn) (2) Al (Fe-Mn-Cr) (3) $\mathrm{Al}$ (Mg-Si) (4) $\mathrm{Al}-\mathrm{Mg}$
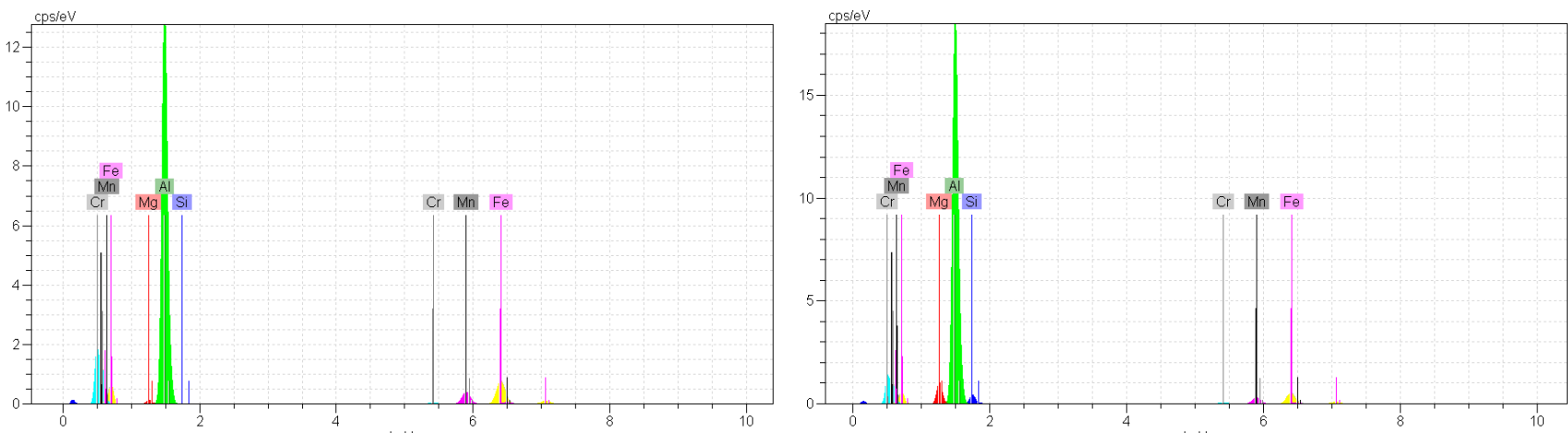

a

b
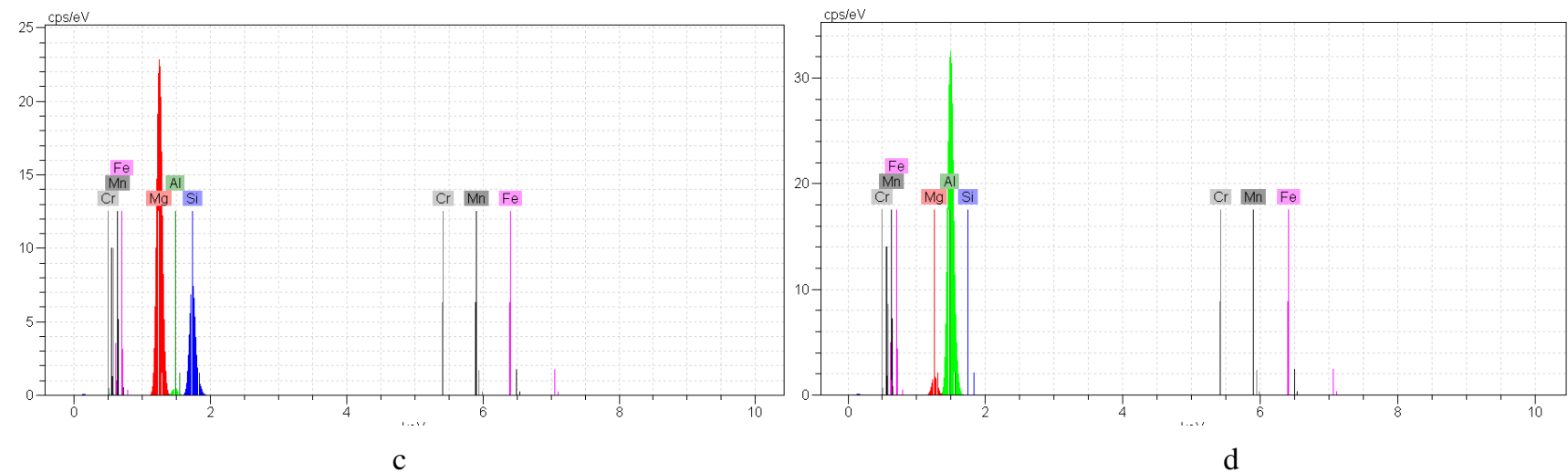

Fig. 3 EDS spectrums acquired on the intermetallic precipitate: a - $\mathrm{Al}(\mathrm{Fe}-\mathrm{Mn}) ; \mathrm{b}-\mathrm{Al}(\mathrm{Fe}-\mathrm{Mn}-\mathrm{Cr}) ; \mathrm{c}-\mathrm{Al}(\mathrm{Mg}-\mathrm{Si})$; $\mathrm{d}-\mathrm{Al}-\mathrm{Mg}$

\subsection{Micro-structures of the weldments}

The SEM micrographs taken from different weld regions of all weldments at various welding speeds are shown in Figs. 4 and 5. From the micrographs it is understood that although all of the identified particles in the parent alloy appear in the WNZ and HAZ areas at the welding speed of $63 \mathrm{~mm} / \mathrm{min}$, the number and size of the particles of each type present at the WNZ and HAZ areas are different. On the other hand, at higher welding speeds of 80 and $100 \mathrm{~mm} / \mathrm{min}$, the particles conditions are different as opposed to the welding speed of $63 \mathrm{~mm} / \mathrm{min}$. In this regard, as can be seen from Fig. 4, the size and distribution of the $\mathrm{Al}(\mathrm{Fe}-\mathrm{Mn})$ and $\mathrm{Al}(\mathrm{Fe}-\mathrm{Mn}-\mathrm{Cr})$ particles decrease in the HAZ region with increasing the welding speed from 63 to $100 \mathrm{~mm} / \mathrm{min}$.

Increasing the welding speed has affected the heat input, leading to decrease in the heat input. Due to the decrease of the heat input and the rising of the cooling rate, the particles cannot grow in the matrix. Additionally, owing to the higher peak temperature and stirring at the welding speed of $63 \mathrm{~mm} / \mathrm{min}$ compared to the other welding speeds, the coarsening mechanism causes the increase of the particles size and distribution [9]. Moreover, with increasing the peak temperature, some of the $\mathrm{Al}(\mathrm{Fe}-\mathrm{Mn}-\mathrm{Cr})$ particles join to the $\mathrm{Al}(\mathrm{Fe}-\mathrm{Mn})$ particles and create the 
coarse particles of $\mathrm{Al}(\mathrm{Fe}-\mathrm{Mn})$ with higher area fraction.

From Figs. 4 and 5, it is found that as the welding speed increase from 63 to $100 \mathrm{~mm} / \mathrm{min}$, the shape of the particles is altered from irregular to semi-circle shape in the WNZ area as opposed to the HAZ. The amount of particles distribution is more uniform at the WNZ area compared to the HAZ region. Meanwhile, the size and number of the Al-Mg particles are higher at the WNZ area than those that at the HAZ area. The solution temperature of the $\mathrm{Al}-\mathrm{Mg}$ particle is almost $450^{\circ} \mathrm{C}$ [10] and because the peak

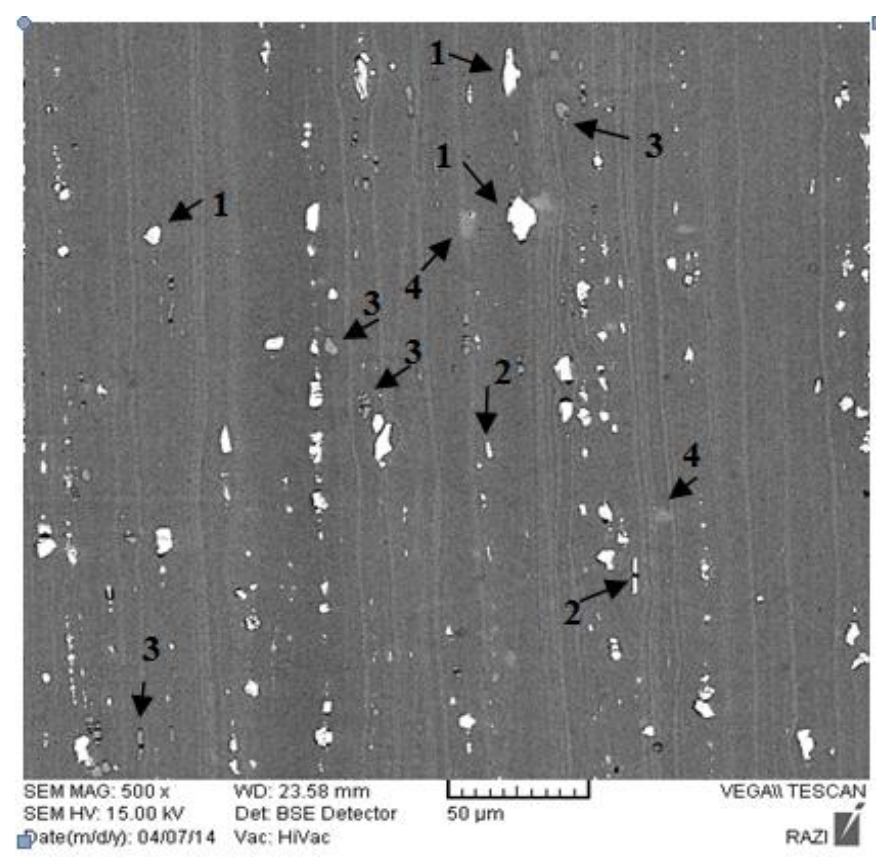

a

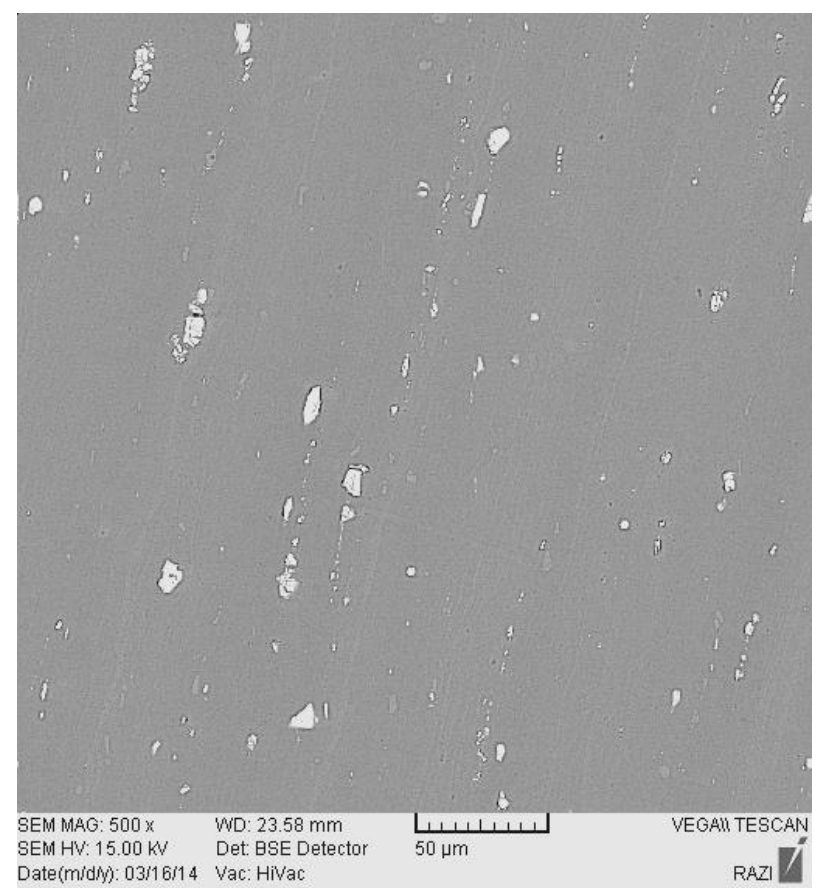

C temperature at the weld region increases above $400^{\circ} \mathrm{C}$ with decreasing the welding speed $[4,5]$, some of these particles dissolve in the matrix. Due to the insufficient of cooling rate in the weld region, the $\mathrm{Al}-\mathrm{Mg}$ particles are formed and grow again in the weld region. That is to say, because of higher temperature at the WNZ compared to the HAZ region, the particle size of the Al-Mg increases with coarsening mechanism which is attributed to the larger diffusion coefficient of the $\mathrm{Mg}$ than the $\mathrm{Al}$ matrix.

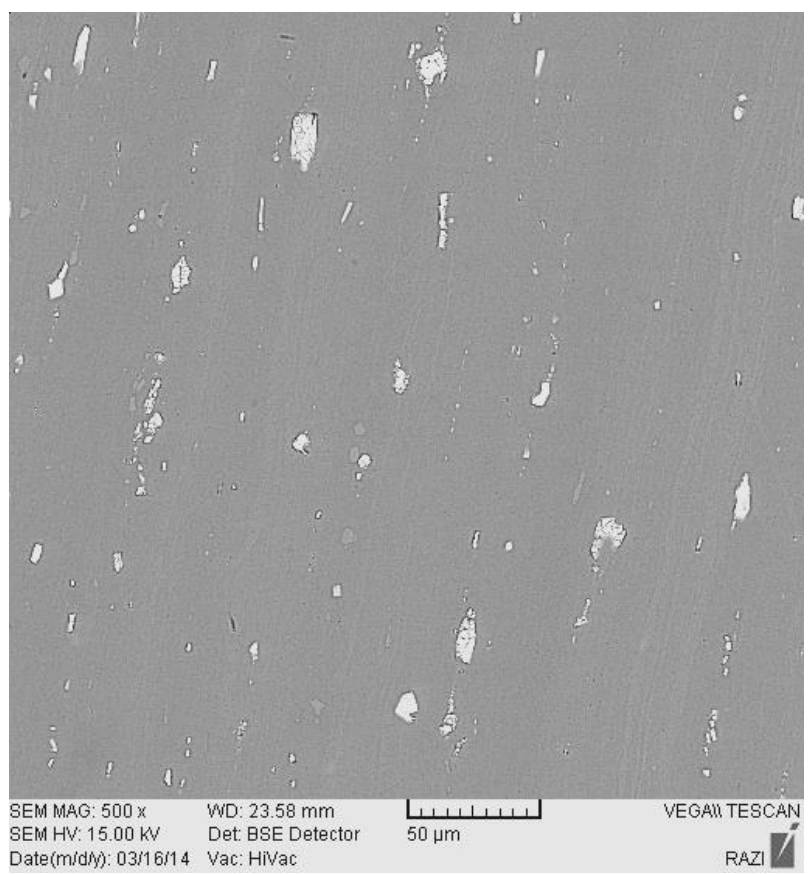

b

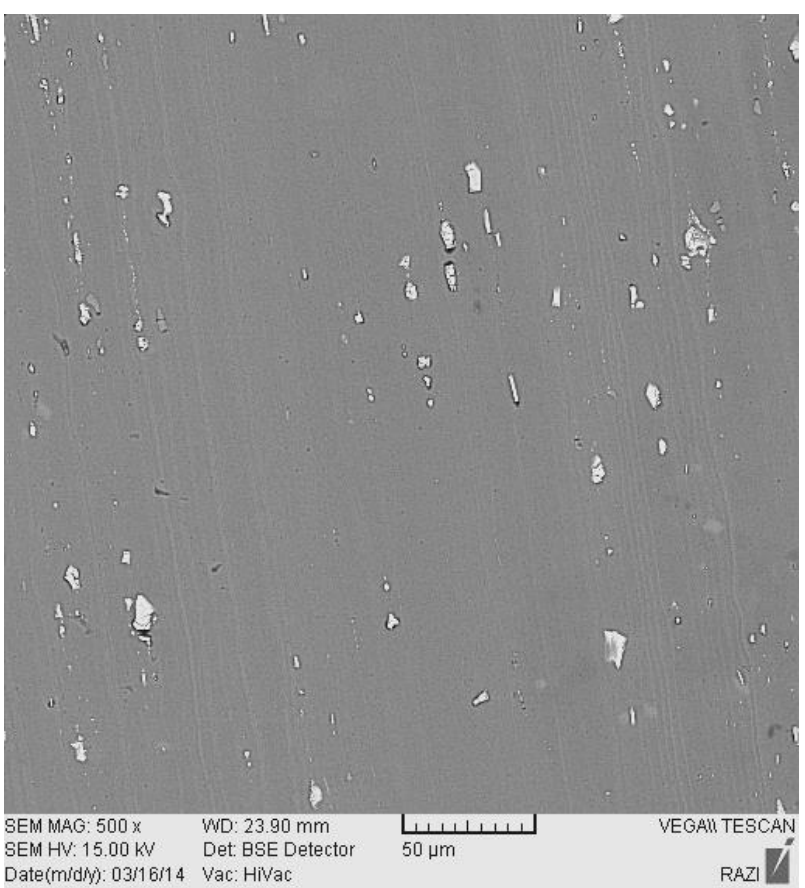

d

Fig. 4 SEM micrograph images of intermetallic identified in the HAZ at different welding speeds: $a-P A ; b-$ formed at $63 \mathrm{~mm} / \mathrm{min}$; c - formed at $80 \mathrm{~mm} / \mathrm{min}$; d - formed at $100 \mathrm{~mm} / \mathrm{min}$. (1) $\mathrm{Al}(\mathrm{Fe}-\mathrm{Mn})$ (2) $\mathrm{Al}(\mathrm{Fe}-\mathrm{Mn}-\mathrm{Cr})(3) \mathrm{Al}(\mathrm{Mg}$ Si) (4) Al-Mg 


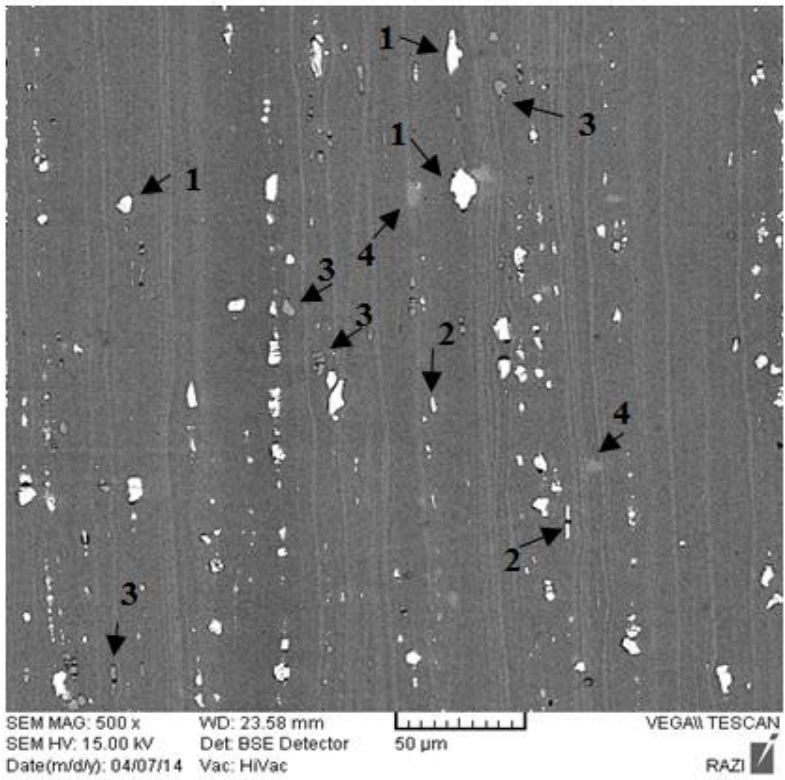

$\mathrm{a}$

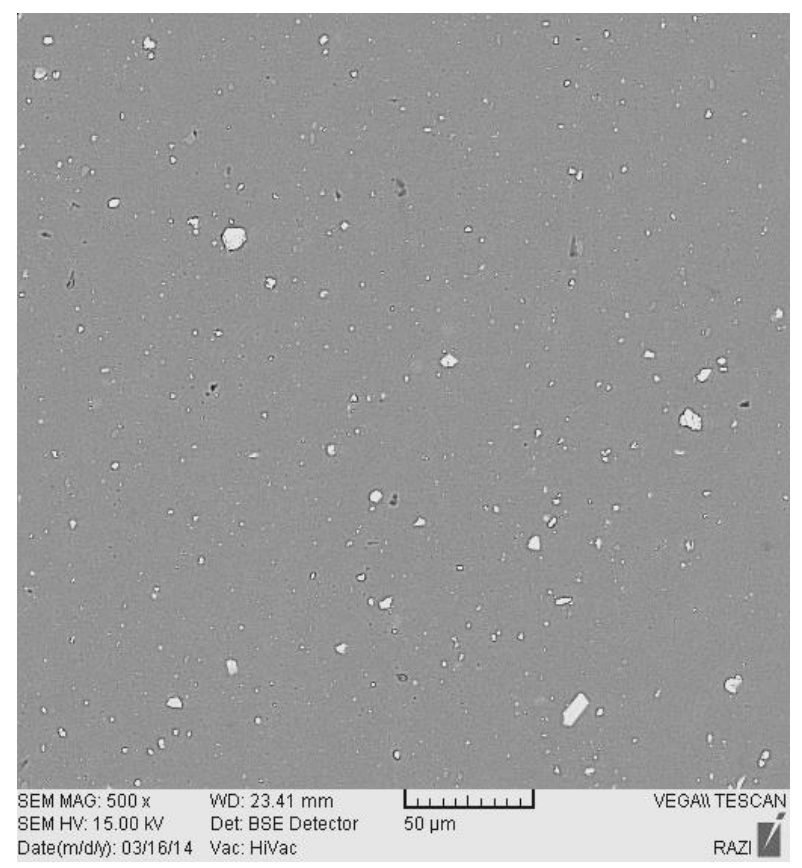

C

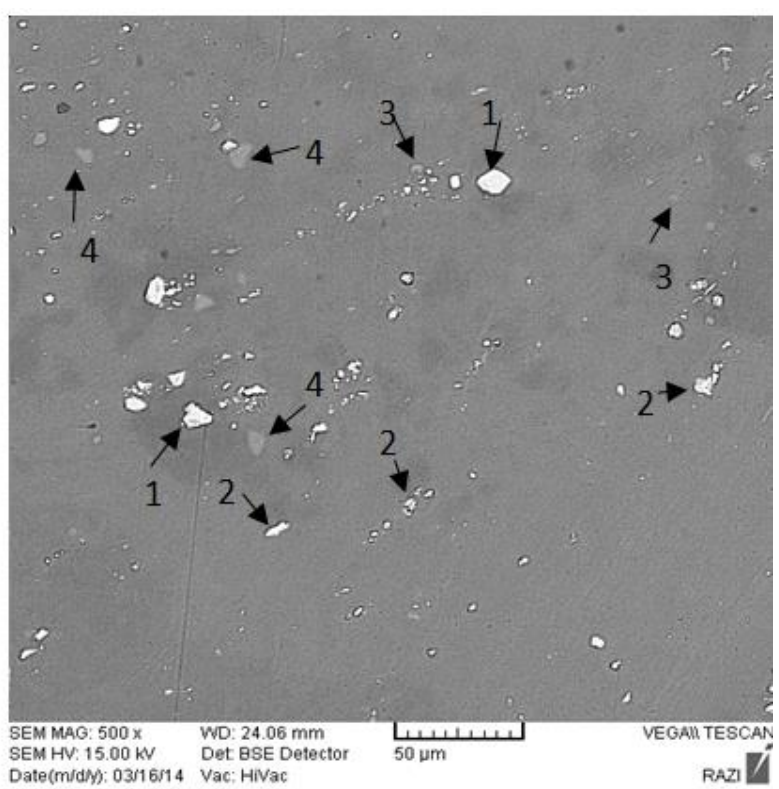

$\mathrm{b}$

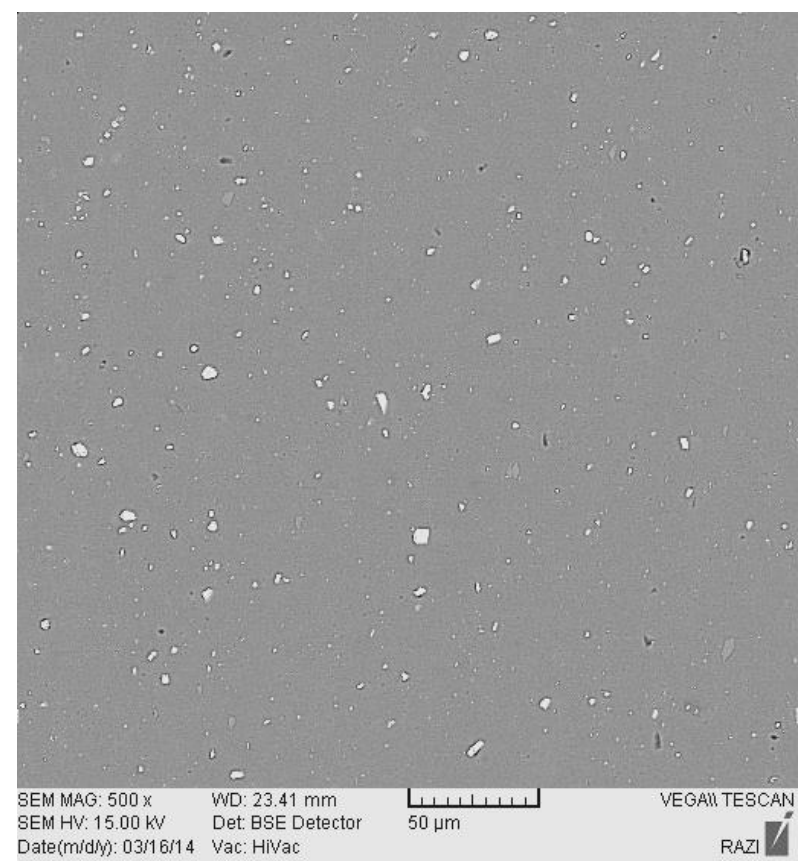

d

Fig. 5 SEM micrograph images of intermetallic identified in the WNZ at different welding speeds: a - PA; b - formed at $63 \mathrm{~mm} / \mathrm{min}$; c - formed at $80 \mathrm{~mm} / \mathrm{min}$; d - formed at $100 \mathrm{~mm} / \mathrm{min}$. (1) $\mathrm{Al}(\mathrm{Fe}-\mathrm{Mn})$ (2) $\mathrm{Al}(\mathrm{Fe}-\mathrm{Mn}-\mathrm{Cr})(3) \mathrm{Al}(\mathrm{Mg}$ $\mathrm{Si})$ (4) Al-Mg

\subsection{Micro-hardness distribution of the weldments}

Microhardness distribution on various weld regions of the solid-solution aluminium alloys has shown more different behaviour than the precipitation hardening aluminium alloys $[4,11]$. Accordingly, there is a softening region in the weld region of precipitation hardening alloys which is attributed to the weakening of precipitate deterioration in the weld region as a result of the heat input during joining. However, generally, there is a homogeneous hardness profile in the solid-solution hardening alloys which can be related to the density of dislocations and strain hardening mechanism of alloys [12]. Microhardness distribution is measured along the mild thickness line of crosssection of the joints. Fig. 6 shows the hardness profile obtained from across the nugget region in all the joints welded at different welding speeds. In this regard, other researchers [11, 13-16] have reported that such behaviour of the hardness profile not only depends mainly on the density of dislocations but also is controlled distribution and size of the $\mathrm{Al}_{6}(\mathrm{Mn}, \mathrm{Fe})$ precipitates. According to Fig. 6, the highest hardness scattering is shown in the joint welded at $63 \mathrm{~mm} / \mathrm{min}$ on the retreating side (RS). This is attributed to the heterogeneity of the precipitates size and their distribution due to the high heat input during the joining process. On the other hand, the hardness profile of the weldments is roughly homogeneous with minimal changes and fluctuations with increasing the welding speed. In this regard, other researchers $[11,13-16]$ have reported that such behaviour of the hardness profile not only depends 
mainly on the hardness scattering of the joint welded at $63 \mathrm{~mm} / \mathrm{min}$ might be related to the fact that during hardness measurement, the indentor is penetrated in a location without any precipitate and it is impressed on the alloy matrix, while in other places where the hardness is high, the indentor may have been located on the precipitates $[9,14-16]$.

Based on Fig. 6 and with increasing the welding speed, it is clear that the size of the weld nugget region decreases. However, Fig. 7 shows that the hardness of the weld nugget region increases at higher welding speed. It should be noted that the heat input decreases with increasing the welding speed during the welding process [4]. Therefore, the growth of precipitates into the weld nugget region decreases at higher welding speed and homogeneity of the precipitates distribution remains constant at higher welding speed $[9,14,16]$. This means that the highest hardness is obtained in the weld nugget zone.

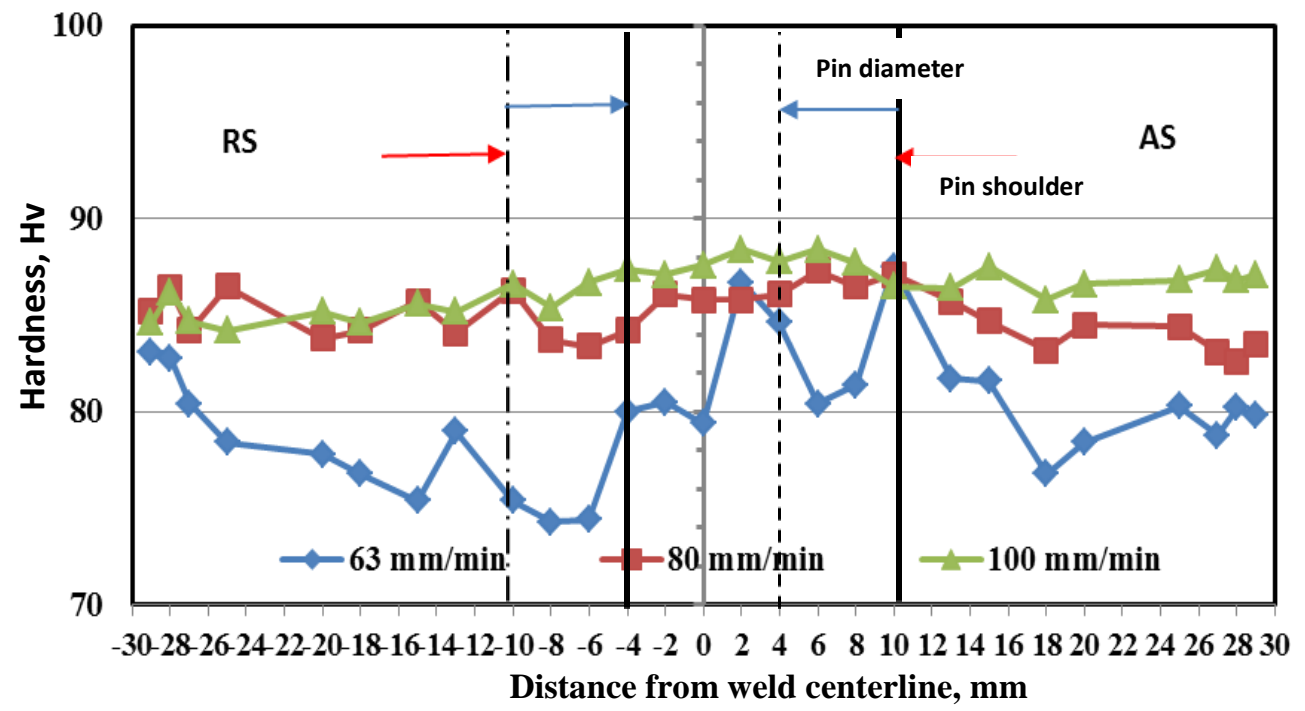

Fig. 6 Microhardness distributions of the joints welded at different welding speeds

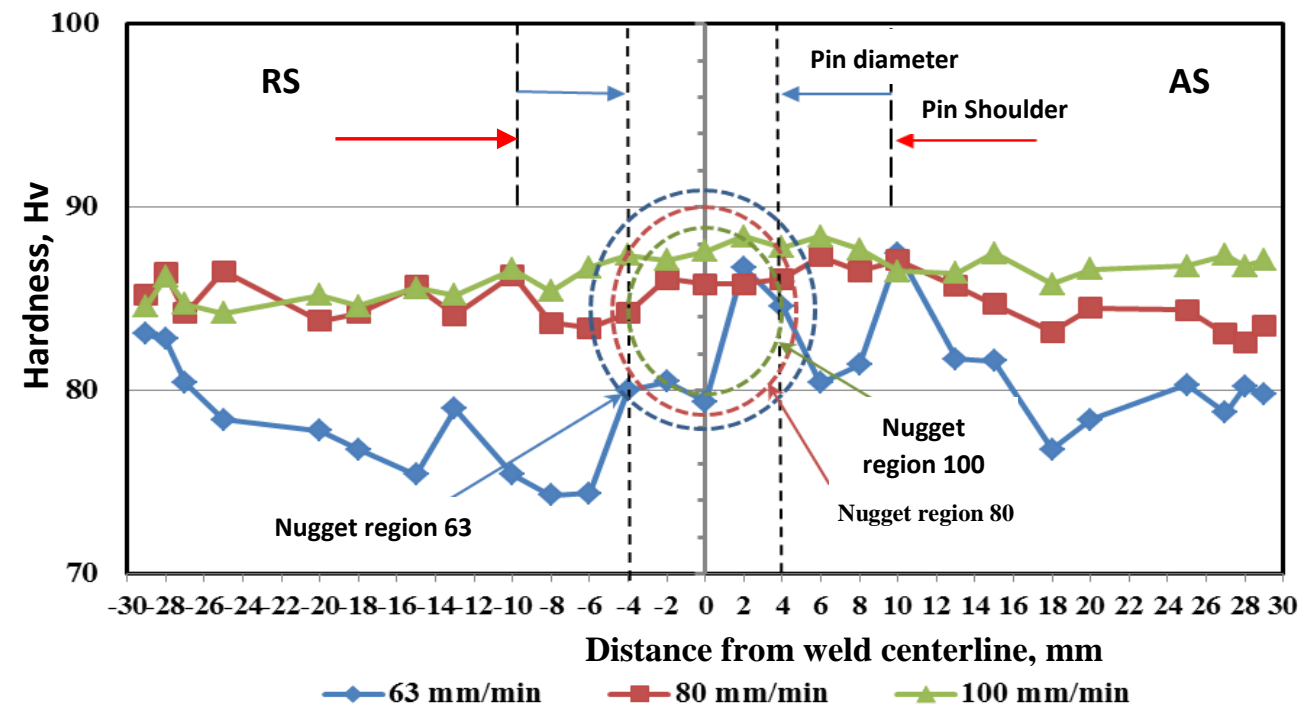

Fig. 7 Relationship between hardness of the weld nugget region at joints welded and different welding speeds

\subsection{Tensile properties of the weldments}

Tensile properties of the joints as a function of welding speed are shown in Fig. 8. The tensile strength increases with increasing the welding speed from 63 to $100 \mathrm{~mm} / \mathrm{min}$. The maximum tensile strength is found to be around $235 \mathrm{MPa}$, equivalent to $70 \%$ of the parent alloy. The joint ductility shows a behaviour similar to the tensile strength, and the maximum elongation, $8.75 \%$, is obtained at the welding speed of $100 \mathrm{~mm} / \mathrm{min}$, equivalent to $25 \%$ of that of the parent alloy. This amount of ductility, i.e. $25 \%$, is very common in the Al-alloys (practically cold-work or precipitation hardened grades) because of the loss of strength within the weld nugget zone [17]. It should be mentioned that the recrystallization process is not completed with increasing the welding speed due to the refining of the grains and their uniform distributions within alloy matrix [18]. Therefore, the strength of the weldments will increase. In other words, the welding speed should be selected in a proper range in order to achieve high-quality joint through friction stir welding of the AA 5086 aluminium alloy. 


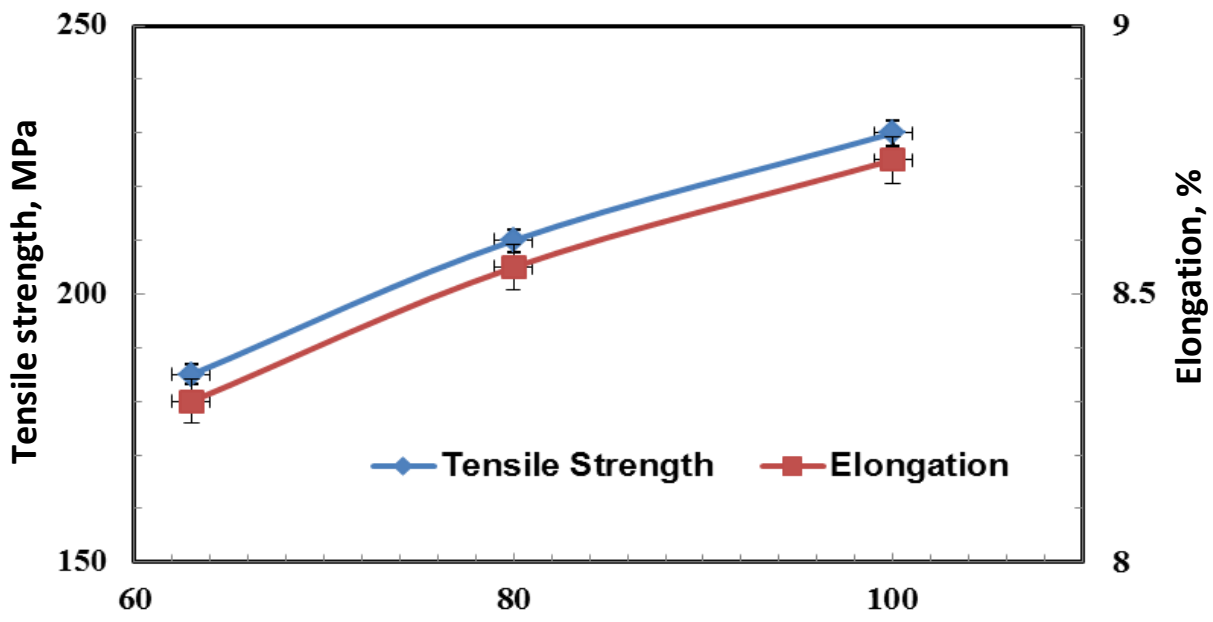

Fig. 8 Tensile properties of the joints welded at different welding speeds. Error bars based on the standard deviation

\section{Conclusion}

A 5086 aluminum alloy has been friction stir welded and the effect of the welding speed on microstructure and mechanical properties of the weldments was investigated. The following conclusions have been drawn from the present research:

The hardness profile of the weldments is roughly homogeneous with minimum fluctuations with increasing the welding speed.

The best combination of tensile strength and ductility (i.e. $70 \%$ and $25 \%$, respectively) was achieved from the fabricated joint with a welding speed of $100 \mathrm{~mm} / \mathrm{min}$.

Three kinds of precipitates are identified in the HAZ and the parent alloy. They are mostly consisting of $\mathrm{Al}-\mathrm{Fe}-\mathrm{Mn}-(\mathrm{Cr})$ ، $\mathrm{Al}-\mathrm{Mg}-\mathrm{Si}$ and $\mathrm{Al}-\mathrm{Mg}$. However, there were only Al-Fe-Mn-(Cr) and Al-Mg-Si precipitates in the weld nugget region.

Due to the existence of stirring, the size of the precipitates decreased in the WNZ area as opposed to the HAZ region and the parent alloy.

The Al-Mg precipitates were fully dissolved by decreasing the welding speed owing to their low melting.

The size of the weld nugget zone decreases with increasing the welding speed due to the decreasing the level of the material flow around the tool pin.

\section{References}

1. Cam, G.; Guclure, S.; Cakan, A.; Serindang, H.T. 2009. Mechanical properties of friction stir butt-welded Al-5086 plate, Materials and Corrosion 4: 638-642.

2. Taban, E.; Kaluc, E. 2005. Comparison between microstructure characteristics and joint performance of 5086-H32 aluminium alloy welded by MIG, TIG and friction stir welding processes, Kovove Materialy 45: 241-248.

3. Kissell, J.R.; Ferry, R.L. 1995. Aluminium Structures, John Wiley\&Sons Inc., USA, pp. 10-13.

4. Mishra, R.S.; Ma, Z.Y. 2005. Friction stir welding and processing, Materials Science and Engineering R, 50: $1-78$. http://dx.doi.org/10.1016/j.mser.2005.07.001.

5. Thomas, W.M. 1991, Friction stir welding, international patent application PCT/GB92, Patent application GB9125978.8.
6. Dilip, J.; Koilraj, M.; Sundareswaran, V.; Ram, G.; Rao, S. 2010. Microstructural characterization of dissimilar friction stir welds between AA2219 and AA5083, Transactions of The Indian Institute of Metals 63: 757-764.

http://dx.doi.org/10.1007/s12666-010-0116-8.

7. Nandan, R.; DebRoy, T.; Bhadeshia, H. 2008. Recent advances in friction-stir welding-process, weldment structure and properties, Progress in Materials Science 53: 980-1023.

http://dx.doi.org/10.1016/j.pmatsci.2008.05.001.

8. Su, J.; Nelson, T.; Mishra, R.; Mahoney, M. 2003. Microstructural investigation of friction stir welded 7050-T651 aluminium, Acta Materialia 51 713729.

http://dx.doi.org/10.1016/S1359-6454(02)00449-4.

9. Li, Y.J.; Arnberg, L. 2003, Evolution of eutectic intermetallic particles in DC-cast AA3003 alloy during heating and homogenization, Materials Science and Engineering A 347: 130-135.

http://dx.doi.org/10.1016/S0921-5093(02)00555-5.

10. Choi, D.H.; Ahn, B.W.; Quesnel, D.J.; Jung, S.B. 2013. Behavior of $\beta$ phase in AA5083 during friction stir welding, Intermetallics 35: 120-127.

http://dx.doi.org/10.1016/j.intermet.2012.12.004.

11. Lee, W.B.; Yeon, Y.M.; Jung, S.B. 2003. The improvement of mechanical properties of friction-stirwelded A356 Al alloy, Materials Science and Engineering A 355: 154-160. http://dx.doi.org/10.1016/S0921-5093(03)00053-4.

12. Taban, E. 2004. Investigation on Mechanical and Microstructural Properties of TIG, MIG and FS Welded 5xxx Series Aluminium Alloys. [MSc Thesis]. Kocaeli University, Turkey.

13. Svensson, L.E.; Karisson, L.; Larsson, H.; Fazzini, B. 2000. Microstructure and mechanical properties of friction stir_welded_aluminium alloys with special reference to AA 5083 and AA 6082, Science and Technology of Welding and Joining 5: 285-296. http://dx.doi.org/10.1179/136217100101538335.

14. Sato, Y.S.; Kokowa, H.; Enomoto, M.; Jorgan, S. 1999. Microstructural evolution of 6063 aluminum during friction-stir welding, Metallurgical and Materials Transaction A 30: 2429- 2437. http://dx.doi.org/10.1007/s11661-999-0251-1. 
15.Sato, Y.S.; Kokowa, H.; Enomoto, M.; Jorgan, S. 1999. Precipitation sequence in friction stir weld of 6063 aluminum during aging, Metallurgical and Materials Transaction A 30: 3125- 3130.

16. Sato, Y.S.; Kokowa, H.; Enomoto, M.; Jorgan, S. 2001. Microstructural factors governing hardness in friction-stir welds of solid-solution-hardened $\mathrm{Al}$ alloys, Metallurgical and Materials Transaction A 30: 30333042. http://dx.doi.org/10.1007/s11661-001-0178-7.

17. Çam, G.; Güçlüer, S.; Çakan, A.; Serindă̆, H.T. 2008. Mechanical properties of friction stir butt-welded Al-5086 H32 plate, Journal of Achievements in Materials and Manufacturing Engineering 30: 151-156.

18. Huang, H.W.; Ou, B.L.; Tsai, C.T. 2008. Effect of homogenization on recrystallization and precipitation behavior of 3003 aluminum alloy, Materials Transactions 49: 250-259.

http://dx.doi.org/10.2320/matertrans.MRA2007615.
K. Amini, F. Gharavi

MICROSTRUCTURE AND MECHANICAL PROPERTIES OF AA5086 ALUMINUM ALLOY BY FRICTION STIR WELDING

S u m m a r y

The present study describes the influence of the welding speed on the microstructure and mechanical properties of 5086 aluminum alloy joints fabricated by friction stir welding. The joints were welded at a constant rotation speed of $100 \mathrm{rpm}$ and different welding speeds ranging from 63 to $100 \mathrm{~mm} / \mathrm{min}$. The experimental results revealed that the nugget size decreases with increasing the welding speed. Although all of the identified particles in the parent alloy appeared in the WNZ and HAZ areas at the welding speed of $63 \mathrm{~mm} / \mathrm{min}$, the number and size of the particles of each type present at these areas were different. Additionally, at higher welding speeds of 80 and $100 \mathrm{~mm} / \mathrm{min}$, the particles conditions were different as opposed to the welding speed of $63 \mathrm{~mm} / \mathrm{min}$. The hardness profile of weldments was roughly homogeneous with minimal fluctuations with increasing the welding speed. The tensile strength increased with increasing the welding speed from 63 to $100 \mathrm{~mm} / \mathrm{min}$. The joint ductility showed a behavior similar to the tensile strength.

Key words: Friction stir welding, aluminum alloy, mechanical properties, welding speed.

Received July 09, 2015

Accepted January 19, 2016 